\title{
Pengaruh Kepemilikan Aset Investasi, Pengetahuan Bisnis Online, Literasi Keuangan dan Ekspetasi Pendapatan Terhadap Minat Bisnis Online Era Pandemi COVID-19
}

\author{
Fatimah Pohan \\ Universitas Nahdlatul Ulama Sumatera Utara, Medan, Indonesia \\ Email: fatimahpohan1976@gmail.com \\ Submitted: 22 Februari 2021; Accepted: 27 Februari 2021; Published: 28 Februari 2021
}

\begin{abstract}
Abstrak-Pembangunan ekonomi secara individual sangatlah bergantung kepada apa yang dimiliki oleh masing-masing diri dan lingkungan juga membantu membentuk seseorang dalam pencapaian kesuksesan masing-masing individu terutama setelah hadirnya internet memberikan banyak kemudahan serta peluang masyarakat dalam mencapai tujuan dengan skala besar, internet juga dianggap mempermudah masyarakat dalam menghadapi masalah krisis ekonomi karena keadaan era pandemi Covid-19 yang banyak membuat masyarakat harus menerima kehilangan pekerjaan karena sulitnya masayarakat dalam berinteraksi dan melakukan kegiatan secara bersamaan dan berdekatan karena wabah virus yang mudah menular sehinggan masyarakat harus mampu menyesuaikan diri melihat peluang terbuka demi mampu bertahan hidup dan membangkitkan perekonomian pada masa era pandemi Covid-19 salah satunya dengan cara membuka peluang bisnis sendiri menggunakan internet yang biasa dikenal dengan jual beli online, tetapi banyak masyarakat yang tidak bias mengambil jalur yang sama dikarenakan beberapa faktor, pada penelitian ini akan melihat pengaruh kepemilikan asset invesstasi, pengetahuan bisnis, literasi keuangan dan ekspetasi pendapatan yang akan diraih jika melakukan bisnis online pada era pandemic covid-19.
\end{abstract}

Kata Kunci: Aset Investasi, Pengetahuan Bisnis, Literasi Keuangan, Bisnis Online, SPSS

\begin{abstract}
Individual economic development is very easy and affordable by what each individual has and the environment also helps someone in the success of each individual, especially after the presence of the internet provides many benefits and opportunities for society to achieve goals on a large scale, the internet is also help make it easier for the community to deal with the problem of the economic crisis due to the conditions of the Covid-19 pandemic era which made many people have to accept jobs because of the difficulty of the community in being able to carry out activities together and closely because the epidemic is contagious so that people must be able to adjust to open opportunities to be able survive and revive the economy during the Covid-19 pandemic era, one of which is by opening up their own business opportunities using the internet which is commonly known as buying and selling online, but many people are not biased. how many factors, in this study will look at the influence of asset ownership, business knowledge, financial literacy and income expectations that will be achieved if you do business online in the era of the Covid-19 pandemic.
\end{abstract}

Keywords: Investment Assets, Business Knowledge, Financial Literacy, Online Business, SPSS

\section{PENDAHULUAN}

Teknologi memberikan dampak positif yang cukup besar dalam kehidupan manusia terutama dalam kehidupan perekonomian manusia, teknologi membantu manusia dalam mengembangkan banyak kemudahan dan ilmu pengetahuan manusia teknologi merupakan bagian terpenting dalam mempermudah dan sebagi mobilisator manusia dalam melakukan ketiatan yang cukup memakan waktu, Teknologi memberikan dampak positif yang cukup besar dalam kehidupan manusia terutama dalam kehidupan perekonomian manusia, teknologi membantu manusia dalam mengembangkan banyak kemudahan dan ilmu pengetahuan manusia teknologi merupakan bagian terpending dalam mempermudah dan sebagi moblisator manusia dalam melakukan ketiatan yang cukup memakan waktu, teknologi sangat membantu manusia dalam setiap bidang kehidupan manusia terutama setelah terciptanya internet, semankin mempermudah manusia dalam hal waktu, dan keuangan. Teknologi yang berkembang pesat dengan vasilitas akses internet merupakan hal yang sangat membantu manusia terutama dalam dunia usaha dan dunia industri mengurangi setiap biaya terhadap kegiatan industri, teknologi terhitung sebagai infrastruktur yang paling dibutuhkan dalam mencapai tujuan pengembangan banyak pihak pelaku dalam dunia industri dan dunia usaha(van der Westhuizen \& Goyayi, 2020).

Adanya internet memberikan kemudahan akses dalam mendapatkan informasi dan pengetahuan yang dan luas $d$ internet juga memperkenalkan manusia dalam mendapatkan gagasan-gagasan baru terutama dalam dunia bisnis seperti memberikan kemudahan kepada masyarakat yang ingin memiliki usahan sendiri tanpa harus mengeluarkan dana dan waktu yang lama untuk mencari tempat memulainya suatu usaha sehingga dalam dunia bisnis dapat dilakukan secara online Karena adanya teknologi yang memberikan kemudahan melakukan transaksi online dengan kemudahan mengakses dengan adanya internet(Kirana et al., 2020). Pentingnya memulai sebuah usaha online maupun bisnis online menentukan seseorang mmampu bertahan pada masa-masa sulit demi mempertahankan keberlangsungan hidup terutama pada era pandemic Covid-19.

Era pandemi Covid-19 adalah sebuah kejadian adanya virus yang cukup mematikan bagi umat manusia diseluruh penjuru bumi, virus ini merupakan virus yang pernah ada sebelumnya dan penyebaran virus ini sangatlah cepat dalam hitungan bulan sudah menyebar hingga keseluruh bagian bumi, virus dikatakan mudah menular melalui percikan air liur oeang yang sudah terinfeksi dan juga dapat tertular melalui udara hal tersebut membuat banyak pemerintah diseluruh penjuru dunia melakukan penegakan peraturan agar masyarakatnya tidak banyak melakukan aktivitas diluar rumah dan tetap berada didalam rumah agar tidak terinfeksi dalam kurun waktu yang cukup lama, hal ini mengakibatkan lumpuhnya perekonomian dunia karena tidak adanya aktivitas yang bisa dilakukan seperti pada umumnya(Elrhim \& Elsayed, 2020). 
Akibat banyaknya aktivitas yang ditutup dan mengakibat perekonomian dunia semakin merosot tajam mengakibatkan banyak perusahaan yang menutup perusahaannya sehingga memutuskan untuk melakukan pemberhentian kerja karyawan dan meningkatkan jumlah pengangguran dan hal tersebut membuat banyak masyarakat yang melakukan pengalihan pekerjaan dengan memulai bisnis online demi mampu bertahan hidup pada masa pandemi Covid-19.

Tinggi angka pengangguran yang terjadi akibat pandemi sangat mempengaruhi peminat pengguna internet emakin tinggi Karen asemua akses fitur dan kemudahan yang disediakan oleh situs-situs e-commerce terkemuka, tingginya angka peminat pembelian melalui e-commerce atau market online membuka peluang banyak orang yang ingin memulai bisnis online, banyak jenis bisnis yang bisa diterapkan dalam bisnis online, tetapi tidak semua tingkat dan kalangan masyarakat yang memahami dan mencoba untuk memulai bisnis baru dengan merambah kepada minat bisnis online dikarenakan beberapa faktor tertentu sehingga masih banyak masyarakat yang bersikeras melakukan aktivitas seperti biasa tanpa memikirkan resiko yang akan terjadi kedepannya(Astari et al., 2020).

Untuk dapat memulai sebuah bisnis online setiap orang juga dapat melakukannya tetapi akan menjadi hal yang sia-sia dan banyak terjadi kegagalan dalam memulai usaha bisnis online jika tidak memiliki dana untuk membeli bahan atau produk yang ingin dipasarkan untuk memulai bisnis online, salah satu faktor pendukung mudahnya terwujud bisnis online juga berkaitan dengan kepemilikan dana yang bisa saja dana tersebut bersumber dari hasil pekerjaan sebelumnya yang telah dialokasikan menjadi dana investasi yang dapat diperoleh kapan saja, harus memiliki pengetahuan bisnis online agar tidak mudah tertipu oleh pelaku transaksi online dan mampu menghindari resiko kedepannya, mengetahui tentang literasi keuangan atau keadaan keuangan karena untuk melakukan bisnis online sangat diperlukan kemampuan dalam pengetahuan keuangan dan pendorong untuk seseorang mau memulai bisnis online dengan membayangkan penghasilan yang akan diperoleh nantinya jika melakukan transaksi oline dari bisnis online.

pada penelitian ini bertujuan untuk mengetahui pengaruh pengaruh kepemilikan aset investasi, pengetahuan bisnis online, literasi keuangan dan ekspetasi pendapatan terhadap minat bisnis online era pandemi covid-19 dengan bantuan alat berupa alat analisa yang dikeluarkan oleh IBM berupa alat penghitung data statistic yaitu SPSS versi 22 agar mempermudah penelitian dalam mencapai dan memperoleh informasi dalam bentuk persenatase.

Pada penelitian terdahulu memperlihatkan beberapa penerapan SPSS dalam membantu pengujian terdahulu dan terdapat penelitian yang berkaitan dengan penelitian sebelumnya seperti " Efikasi Diri Dan Keluarga Terhadap Minat Wirusaha Siswa SMK Di Masa Pandemi Covid-19(WIDIANINGRUM; Enggar., 2020)”,” Dampak Covid 19 Terhadap UMK Dan Pentingnya Literasi Keuangan Dan Teknologi Dalam Mempertahankan Kelangsungan Bisnis Kuliner Di Kota Kupang (Jati et al., 2021)" dan lain-lain.

\section{METODOLOGI PENELITIAN}

Penelitian ini mengguanakn terapan metode kuantitatif dan melakukan tahapan dan pengolahan data kuantitatif untuk melihat hubung-hubungan kepada fenomena-fenomena yang berhubungan dengan objek penelitian metode ini lebih mengarah kepada model-model sistematis matematik(Albi Anggito \& Johan Setiawan, 2018).

\subsection{Pengumpuan Data}

Pengumpulan data menggunakan dilakukan dalam bentuk sebagai berikut ini:

1. Observasi

Teknik Observasi merupakan kegiatan yang turun kelapangan langsung untuk melakukan pengumpulan data dan informasi terhadap populasi tetapi data yang dituju masih dalam ruang lingkup yang relatif kecil.

2. Kuesioner

Kuesioner yaitu setelah melakukan observasi langsung terhadap narasumber yang ingin dituju selanjutnya dilakukan penyebaran kuesioner yaitu berupa rangkaian pertanyaan yang terkait kepada penelitian tetapi kuesioner dapat

3. Studi literatur

Melakukan aktivitas membaca sumber-sumber ilmu pengetahuan yang terkait kepada penelitian mulai dari buku-buku, jurnal mauun artikel ilmiah(Hasanah, 2017).

\subsection{Kepemilikan Aset Invesatasi}

Pada penelitian ini kepemilikan asset investasi dimaksud dengan seseorang memiiki asset maupun simpanan yang berupa investasi yang telah lama dialokasikan dan dapat menjadi sumberdana yang baik untuk memulai sebuah usaha maupun sumberdana yang dapat dialokasikan ketika terjadi sebuah kondisi maupun keadaan yang tidak memenuhi standart. Kepemilikan asset investasi dapat dimiliki jika seseorang yang memahami keadaan keuangan dan melalui alokasi dana kedalam bentuk segala jenis investasi maupun dapat mengalokasikan dana menjadi investor(Filbert \& Prasetya, 2017).

\subsection{Pengetahuan Bisnis Online}

Pengetahuan bisnis online sangat baik diketahui karena bisnis ini merupakan kegiatan yang menjanjikan provid kedepannya dengan terus melakukan peningkatan ilmu teknologi dan perkembangan zaman, pengetahuan terhadap bisnis online seperti mengetahui sistem informasi yang digunakan, mengetahui mengetahui sistem undang-undang jual beli online, sistem pemesanan dan penjualan, mengetahui sistem transaksi, mengetahui sistem informasi terhadap aplikasi emoney, e-pay dan lain-lain hal tersebut mampu mempermudah dan mengurangi dampak maupun resiko yang terjadi ketika melakukan bisnis online (Anggri Puspita Sari, Dina Dewi Anggraini, Marlynda Happy Nurmalita Sari, Dyah Gandasari, 
Valentine Siagian, Ri Sabti Septarini, Diena Dwidienawati Tjiptadi, Oris Krianto Sulaiman, Muhammad Munsarif, Prima Andreas Siregar, Nur Arif Nugraha, 2020).

\subsection{Literasi Keuangan}

Literasi keuangan merupakan pengetahuan dan kemampuan dalam megolah data keuangan baik pribadi maupun sebuah organisasi, pentingnya literasi ini diketahui untuk membantu dalam proses dan melihat kemampuan terhadap kondisi keuangan. Dan mampu melihat konsep dan setiap resiko-resiko dalam pengolahan keuangan dan literasi ini merupakan kemampuan pengambilan keputusan dalam tingkatan mencapai kesejahteraan terhadap finansial(Yushita, 2017).

\subsection{Expetasi Pendapatan}

Ekspetasi pendapatan merupakan bayangan yang terlintas sebelum kenyataan terjadi atau berupa imajinasi yang terlintas dalam memperoleh pendapatan, biasana ekspetasi lebih berhubungan kepada sebuah pengharapan sehingga ekspetasi pendapatan merupakan harapan yang diinginkan dalam memperoleh penghasilan lebih tinggi sehingga dengan ekspetasi pendapatan yang lebih tinggi membuat seseorang maupun sekelompok orang akan berusaha untuk memperolehnya(Ekspektasi et al., 2021).

\subsection{Tahapan Pengujian Menggunakan SPSS}

Adapun tahapan dalam pengujian ini adalah sebagai berikut ini(Ana Ramadhayanti, 2019):

1. Statistik deskriptif

Untuk mengetahui total data yang terdapat pada kuesioner dan melihat karakteristik nilai sebuah data.

2. Uji instrument

Pada pengujian ini menggunakan dua tahapan yaitu uji validasi untuk melihat valid atau sah sebuah data dan uji reliabel yang berguna untuk melihat konsistensi atau reliabel sebuah data kuesioner.

3 Uji Hipotesis

Pada pengujian ini menggunakan terdiri dari

a. Uji normalitas

b. Uji multikolinearitas

c. Uji heteroskedastisitas

d. Simul taneous Signifikansi Test (F-Test)

e. Uji Signifikansi Parsial (Uji-T)

Setiap pembahasan terhadap pengujian dilakukan menggunakan aplikasi statistik sebagai alat bantu mempermudah dalam mempermudah mendapatkan nilai yang akan diuji menggunakan SPSS versi 22.

\section{HASIL DAN PEMBAHASAN}

Pengolahan data dapat dilakukan dengan menggunakan bantuan tools dalam melakukan analisa yaitu menggunakan SPSS versi 22 untuk melakukan pengujian terhadap mengetahuan terhadap penilaian terhadap pengaruh setiap kompenen variable yang saling berkaitan yang memperlihatkan hasil terhadap minat bisnis online.

\subsection{Statistik Deskriptif}

Tabel 1. Uji Statistik Deskriptif

\begin{tabular}{|c|c|c|c|c|c|c|}
\hline \multicolumn{7}{|c|}{ Descriptive Statistics } \\
\hline & $\mathrm{N}$ & & Minimum & Maximum & Mean & Std. Deviation \\
\hline kepemilikan aset investasi & & 50 & 8 & 20 & 16.44 & 3.693 \\
\hline Pengetahuan Bisnis & & 50 & 8 & 20 & 16.50 & 2.908 \\
\hline Literasi Keuangan & & 50 & 12 & 20 & 16.72 & 2.634 \\
\hline Ekspetasi Pendapatan & & 50 & 12 & 20 & 17.10 & 2.234 \\
\hline Minat Bisnis Online & & 50 & 12 & 20 & 16.62 & 2.118 \\
\hline Valid N (listwise) & & 50 & & & & \\
\hline
\end{tabular}

Perolehan data diatas untuk mengetahui data yang berkaitan dalam kuesioner dan memperlihatkan terhadap jumlah data yang diperoleh dalam sebuah kuesioner beserta nilai yang diperoleh dari keseluruhan data responden.

\subsection{Uji Instrumen Terhadap Data}

Uji instrument adalah tahapan yang cukup penting dalam mengetahui kualitas yang dimiliki oleh data kuesioner yang diolah dari jawaban setiap responden sebagai bentuk keyakinan terhadap data tersebut valid atau sah yang dapat dilakukan dengan menguji validitas dan reliabilitas sebuah data responden.

\subsubsection{Uji Validitas}

Pada uji validitas ini bertujuan untuk mengetahui bahwa data dari responden maupun keseluruhan data yang ada pada peernyataan jawaban kuesioner untuk menunjukan kinerja kerja kusioner tersebut, pada pengujian ini dilakukan dengan membaca data apakah teridentifikasi sebagai data valid atau tidak dengan melakukan kolerasi terhadap nilai yang dimiliki masing-masing nilai pada nomor pernyataan dengan nilai total dan selanjutnya lakukan dengan cara melihat pada $\mathrm{r}$ tabel 
dengan membandingkan jumlah butir pertanyaan dengan melihat apakah valid atau tidak data atau butir pertanyaan dengan hasil responden atau jawaban dari butir pertnyaan dengan melihat $r$ hitung (dari SPSS) $>r$ tabel atau dapat dicari dengan melihat nilai $\mathrm{P}<0,05$ hal tersebut dilihat dari data yang dikumpulkan oleh penguji dengan perbandingan data yang benar-benar terjadi pada objek penelitian dan juga dikumpulkan oleh peneliti.

Tabel 2. Uji Validitas

\begin{tabular}{|c|c|c|c|c|c|c|}
\hline & & KAI & $\mathrm{PB}$ & LK & $\mathrm{EP}$ & $\mathrm{MBO}$ \\
\hline \multirow{3}{*}{$\begin{array}{l}\text { kepemilikan aset } \\
\text { investasi }\end{array}$} & Pearson Correlation & 1 & .096 & .105 & .139 & -.037 \\
\hline & Sig. (2-tailed) & & .505 & .468 & .336 & .800 \\
\hline & $\mathrm{N}$ & 50 & 50 & 50 & 50 & 50 \\
\hline \multirow[t]{3}{*}{ Pengetahuan Bisnis } & Pearson Correlation & .096 & 1 & .127 & .087 & .160 \\
\hline & Sig. (2-tailed) & .505 & & .381 & .547 & .268 \\
\hline & $\mathrm{N}$ & 50 & 50 & 50 & 50 & 50 \\
\hline \multirow[t]{3}{*}{ Literasi Keuangan } & Pearson Correlation & .105 & .127 & 1 & .189 & $.383^{* *}$ \\
\hline & Sig. (2-tailed) & .468 & .381 & & .189 & .006 \\
\hline & $\mathrm{N}$ & 50 & 50 & 50 & 50 & 50 \\
\hline \multirow[t]{3}{*}{ Ekspetasi Pendapatan } & Pearson Correlation & .139 & .087 & .189 & 1 & $.660^{* *}$ \\
\hline & Sig. (2-tailed) & .336 & .547 & .189 & & .000 \\
\hline & $\mathrm{N}$ & 50 & 50 & 50 & 50 & 50 \\
\hline \multirow[t]{3}{*}{ Minat Bisnis Online } & Pearson Correlation & -.037 & .160 & $.383^{* *}$ & $.660^{* *}$ & 1 \\
\hline & Sig. (2-tailed) & .800 & .268 & .006 & .000 & \\
\hline & $\mathrm{N}$ & 50 & 50 & 50 & 50 & 50 \\
\hline
\end{tabular}

Data dikatakan valid jika nilai $r$ hitung lebih besar dari nilai $r$ tabel, nilai $r$ tabel ditemukan pada sampel 50 sesuai pada ketetapan perhitungan jumlah sampel pada tabel 1. Uji statistik deskriptif.

\subsubsection{Uji Reliabilitas}

Pada pengujian reliabilitas dikatakan konsisten jika data tersebut sesuai dengan pengukuran terhadap gejala yang sama tetapi dilakukan pada tempat lain dan pada pengujian ini hanya untuk nomor maupun angka yang sahih saja dan tujuannya untuk menyakinkan terhadap data dari kuesioner yang kita buat benar-benar baik dalam menjadi patokan untuk dilakukan pengukuran pengujian terhadap data gejala yang bersangkutan dan juga menghasilkan data yang konsisten dan tepat.

Table 3. Reliabilitas

\begin{tabular}{cccc}
\hline Variable & $\begin{array}{c}\text { Cronbach's } \\
\text { Alpha }\end{array}$ & r-Table & Result \\
\hline Kepemilikan Aset Investasi & 0,555 & 0,279 & Konsisten \\
Pengetahuan Bisnis Online & 0,437 & 0,279 & Konsisten \\
Literasi Keuangan & 0,353 & 0,279 & Konsisten \\
Ekspetasi Pendapatan & 0,339 & 0,279 & Konsisten \\
Minat Bisnis Online & 0,360 & 0,279 & Konsisten \\
\hline
\end{tabular}

Pada pengujian realibilitas yang dilihat data tersebut konsisten atau tidak adalah pada data Cronbach's Alpha dan nilai pada tabel Cronbach's Alpha harus lebih besar dari pada nilai yang ada pada r-tabel dengan data 50 responden.

\subsection{Uji Hipotesis}

Uji Hipotesis merupakan salah satu pengujian yang terdapat pada cabang ilmu statistika inferensial dan pada penelitian yang menggunakan pengujian hipotesis digunakan untuk melihat sebuah keadaan dimana pada objek yang diteliti akan memperlihatan kebenaran dari sebuah pernyataan secara statistik yang digunakan dalam penarikan kesimpulan terhadap pernyataan benar atau tidak, diterima atau tidak sebuah pernyataan dan asumsi yang telah dibuat dengan menguji dan mengumpulkan beberapa data-data.

\subsubsection{Uji Asumsi Klasik}

Untuk mengarahkan pengujian kepada uji regresi linear berganda danmenghasilkan hipotesis yang sesuai dengan data harus dilakukan uji asumsi klasik yang harus dipenuhi dengan tujuan melakukan perhitungan kepada pada nilai variable tertentu, pengujian asumsi klasis biasanya dilakukan pengujian normalisasi, uji multikolinearita, uji heteroskedastisitas dan lain-lain. Dalam melakukan uji asumsi klasik tidak semua harus diuji tergantung kepada data yang diuji dan tahapan pengujian belum ada ketentukan dalam uji asumsi klasisk ini pengujian apa yang harus dilakukan terlebih dahulu.

1. Uji Normalisasi

Pada uji ini tingkat signifikasi >0,05 dinyatakan normal jika hasil normalisasi menggunakan spss lebih besar dari 0,05 jika lebih kecil maka dinyatakan data tersebut tidak normal. 
Tabel 4. Uji Normalisasi

\begin{tabular}{llr}
\hline \multicolumn{2}{c}{ One-Sample Kolmogorov-Smirnov Test } & Unstandardized Residual \\
\hline $\mathrm{N}$ & & 50 \\
Normal Parameters & & .0000000 \\
& Mean & 1.45607698 \\
Most Extreme Differences & Std. Deviation & .094 \\
& Absolute & .075 \\
& Positive & -.094 \\
Test Statistic & Negative & .094 \\
Asymp. Sig. (2-tailed) & & $.200^{\mathrm{c}, \mathrm{d}}$ \\
\hline
\end{tabular}

Pada penelitian uji normalisasi dapat diketahui dengan melihat 3 cara yaitu membaca gambar histogram, plot yang beraturan dan Kolmogorov, pada pembacaan data dikatakan normalisasi lebih mudah menggunakan Kolmogorov dan data tersebut menunjukan ada Asymp. Sig sebesar 0,200 pada nilai tersebut lebih besar dari skala signifikasi yaitu 0,05 sehingga data responden dari kuesioner sangat normal.

2. Uji Multicollinearity Test

Pada pengujian ini akan melihat apakah data terkena multicollinearity yang berarti adanya sebuah data yang intekolerasi atau adanya sebuah data yang koleniaritas pada variabel bebas dan variabel bebas.

Tabel 5. Uji Multicollinearity

\begin{tabular}{|c|c|c|c|c|c|c|c|c|}
\hline \multicolumn{9}{|c|}{ Coefficients $^{\mathbf{a}}$} \\
\hline \multirow{2}{*}{\multicolumn{2}{|c|}{ Model }} & \multicolumn{2}{|c|}{$\begin{array}{c}\text { Unstandardized } \\
\text { Coefficients }\end{array}$} & \multirow{2}{*}{$\begin{array}{l}\text { Standardized } \\
\text { Coefficients } \\
\text { Beta }\end{array}$} & \multirow[b]{2}{*}{$\mathrm{t}$} & \multirow[b]{2}{*}{ Sig. } & \multicolumn{2}{|c|}{ Collinearity Statistics } \\
\hline & & $\mathrm{B}$ & Std. Error & & & & Tolerance & VIF \\
\hline 1 & (Constant) & 4.271 & 2.294 & & 1.861 & .069 & & \\
\hline & kepemilikan aset investasi & -.087 & .060 & -.152 & -1.462 & .151 & .966 & 1.036 \\
\hline & Pengetahuan Bisnis & -.003 & .078 & -.004 & -.036 & .971 & .917 & 1.090 \\
\hline & Literasi Keuangan & .217 & .087 & .270 & 2.498 & .016 & .899 & 1.112 \\
\hline & Ekspetasi Pendapatan & .597 & .100 & .629 & 5.973 & .000 & .946 & 1.057 \\
\hline
\end{tabular}

a. Dependent Variable: Minat Bisnis Online

Pada pengujian ini dikatakan tidak terkontaminasi jika nilai VIF lebih kecil dari 10 dan nilai toleransinya lebih besar dari 0,1 dan pada data keselururhan variabel dapat dilihat pada kolom Collinearity Statistics dinyatakan tidak terkontamikasi atau terjadi multikoleniaritas

3. Uji Heteroscedasticity

Pada data dibawah ini data disebutkan tidak terkontamnasi pada Heteroscedasticy adalah jika data menyebar dan tidak terjadi tumpukan dalam satu area atau satu titik saja atau menjadi lingkaran hitam yang tebal tampak seperti tumpukan



Gambar 1. Uji Heteroscedasticity

\subsubsection{Uji F ( F - Test )}

pada fungsi ini dilakukan pengujian dalam salah satu ilmu statistika untuk melihat terhadap variabel atau semua variabel bebas terhadap variabel terikat uji ini biasa disebut dengan Uji Anova atau Uji Model.

Tabel 6. Uji F/ Uji Anova

\begin{tabular}{llrrrrr}
\multicolumn{7}{c}{ ANOVA $^{\text {a }}$} \\
\hline Model & & Sum of Squares & df & Mean Square & F & \multicolumn{1}{c}{ Sig. } \\
\hline 1 & Regression & 115.892 & 4 & 28.973 & 12.550 & $.000^{\text {b }}$ \\
& Residual & 103.888 & 45 & 2.309 & & \\
& Total & 219.780 & 49 & & & \\
\hline
\end{tabular}

a. Dependent Variable: Minat Bisnis Online

b. Predictors: (Constant), Ekspetasi Pendapatan , Pengetahuan Bisnis, kepemilikan aset investasi,

Literasi Keuangan 
Ekonomi, Keuangan, Investasi dan Syariah (EKUITAS)

Vol 2, No 2, Februari 2021, Hal 187-193

ISSN 2685-869X (media online)

DOI: 10.47065/ekuitas.v2i2.670

Hasil diapat diketahui dengan melakukan perbandingan hasil uji dalam Anova $F$ tabel $=\mathrm{f}(\mathrm{k} ; \mathrm{n}-\mathrm{k})=\mathrm{F}(4 ; 50-4)=\mathrm{F}(4 ; 46)=$ 2,57

\subsubsection{Uji T (T-Test )}

Tabel 7. Uji T

\begin{tabular}{|c|c|c|c|c|c|}
\hline \multirow[b]{2}{*}{ Model } & \multicolumn{2}{|c|}{$\begin{array}{l}\text { Unstandardized } \\
\text { Coefficients }\end{array}$} & \multirow{3}{*}{$\begin{array}{c}\text { Standardized } \\
\text { Coefficients } \\
\text { Beta }\end{array}$} & \multirow{3}{*}{$\begin{array}{l}\mathrm{t} \\
1.861\end{array}$} & \multirow{3}{*}{$\begin{array}{l}\text { Sig. } \\
.069\end{array}$} \\
\hline & B & Std. Error & & & \\
\hline $1 \quad$ (Constant) & 4.271 & 2.294 & & & \\
\hline $\begin{array}{l}\text { kepemilikan aset } \\
\text { investasi }\end{array}$ & -.087 & .060 & -.152 & -1.462 & .151 \\
\hline Pengetahuan Bisnis & -.003 & .078 & -.004 & -.036 & .971 \\
\hline Literasi Keuangan & .217 & 087 & .270 & 2.498 & .016 \\
\hline Ekspetasi Pendapatan & .597 & .100 & .629 & 5.973 & .000 \\
\hline
\end{tabular}

a. Dependent Variable: Minat Bisnis Online

Cari nilai pada uji $\mathrm{T}$ pada hipotesis dilakukan dengan melihat perbandingan pada $\mathrm{r}$ tabel dengan uji $\mathrm{T}$ yang telah dilakukan, untuk mengetahui nilai $r$ tabel adalah $\mathrm{t}(\mathrm{a} / 2 ; \mathrm{n}-\mathrm{k}-1)$ yang berarti $\mathrm{t}(0,025 ; 50-4-1)$ adalah $\mathrm{t}(0,025 ; 45)$ yang dilihat pada tabel 0,025 baris ke 45 adalah 0,3884 .

\subsection{Hasil Hipotesis}

Hasil hipotesis menunjukan hasil pengaruh dari keseluruhan variabel terikat maupun varibel bebas dalam melihat pengaruh dan hubungan terhadap masing-masing variabel sebagai berikut:

1. H1 yaitu keseluruhan variabel pengaruh kepemilikan asset investasi, pengetahuan bisnis, literasi keuangan, ekspetasi pendapatan terhadap minat bisnis online pada masa pandemi Covid-19 pada total $\mathrm{f}$ tabel hitung sebesar 12,550 dan pada $\mathrm{f}$ tabel ketentuan yang diketahui melalui rumus sebesar 2,57 yang berarti nilai 12,550 $>2,57$ yang berarti sangat berpengaruh kepada keseruhan variabel terikat atau minat bisnis online dengan constant dan memberikan pengaruh yang sangat positif.

2. H2 pada hipotesis ke dua pengaruh kepemilikan asset investasi terhadap minat bisnis online bernilai $-1,462$ yang memiliki nilai minus dari pada nilai perolehan pada t tabel sebesar 0,3884 hasil dinyatakan sangat ditolak karena nilai lebih kecil dari signifikasi pada $t$ tabel parameter dan tidak terlalu berpengaruh signifikan dan nilai digolongan kepada pengaruh signifikasi yang negatif.

3. H3 pada hipotesis pengaruh pengetahuan Bisnis Online terhadap minat bisnis online sebesar $-0,36$ yang memiliki nilai negatif rendah dan sesuai syarat nilai perolehan pada t tabel sebesar 0,3884 hasil dinyatakan sangat ditolak karena nilai lebih kecil dari signifikasi pada $t$ tabel parameter dan tidak terlalu berpengaruh signifikan dan nilai digolongan kepada pengaruh signifikasi yang negatif.

4. H4 yaitu pengaruh Literasi Keuangan terhadap minat bisnis online memiliki nilai sebesar 2,498 yaitu nilai lebih besar daripada parameter yang telah ditentukan pada $t$ tabel sebesar 0,3884 atau dapat dinyatakan 2,498 $>0,3884$ yang berarti hipotesis tersebut diterima kalangan responden dan memiliki pengaruh positif yang sangat besar.

5. H5 yaitu pengaruh ekspetasi pendapatan terhadap minat bisnis online memiliki nilai sebesar 5,973 yaitu nilai lebih besar daripada parameter yang telah ditentukan pada t tabel sebesar 0,3884 atau dapat dinyatakan 5,973>0,3884 yang berarti hipotesis tersebut diterima kalangan responden dan memiliki pengaruh positif yang sangat besar.

Hasil dari data tersebut tergantung kepada menurut dan pendapat pengolahan nilai yang diberikan oleh respondensi yang tertera pada pernyataan-pernyataan terkait pada pengujian dan diramkum dalam bentuk kuesioner, setiap jabawan memiliki pendapat tersendiri oleh masing-masing reponden dan pengujian ini dilakukan untuk melihat pengaruuh dari masing-masing variabel dari pemikiran banyak pihak yang terkait.

\section{KESIMPULAN}

Pada penelitian ini tampak setiap aspek variable bebas dan variable terikat saling mempengaruhi satu dengan yang lainnya, minat dalam bisnis online akan sangat memiliki pengaruh besar dan positif apabila didukung dengan memiliki kemampuan literasi keuangan dan ekspetasi pendapatan yang akan diperoleh dan variable lain memiliki pengaruh yang signifikan dan terhadap minat bisnis online, hasil didapatkan bernilai sebagai pengaruh positif dan berarti diterima oleh banyak pihak dan bersifat pengaruh negatif yang berarti tidak signifikan dan ditolak oleh beberapa pihak yang terkait, penggunaan SPSS mempermudah dalam mengolah data statistik dan mampu memperoleh jawaban pengujian dengan waktu yang singkat dan hasil yang tepat.

\section{DAFTAR PUSTAKA}

Albi Anggito, \& Johan Setiawan. (2018). Metodologi Penelitian Kuantitatif (E. L. Deffi (ed.)). CV Jejak.

Ana Ramadhayanti. (2019). Aplikasi SPSS untuk Penelitian dan Riset Pasa. Elex Media Komputindo.

Anggri Puspita Sari, Dina Dewi Anggraini, Marlynda Happy Nurmalita Sari, Dyah Gandasari, Valentine Siagian, Ri Sabti Septarini, Diena Dwidienawati Tjiptadi, Oris Krianto Sulaiman, Muhammad Munsarif, Prima Andreas Siregar, Nur Arif Nugraha, J. S. 
Ekonomi, Keuangan, Investasi dan Syariah (EKUITAS)

Vol 2, No 2, Februari 2021, Hal 187-193

ISSN 2685-869X (media online)

DOI: 10.47065 /ekuitas.v2i2.670

(2020). Kewirausahaan dan Bisnis Online (A. Rikki (ed.); 1st ed.). Yayasan Kita Menulis.

Astari, N. M. A. J., Dewa Gede Hendra Divayana, \& Gede Indrawan. (2020). Analisis Sentimen Dokumen Twitter Mengenai Dampak Virus Corona Menggunakan Metode Naive Bayes Classifier. Jurnal Sistem Dan Informatika (JSI), 15(1), 27-29. https://doi.org/10.30864/jsi.v15i1.332

Ekspektasi, D. A. N., Terhadap, P., Putra, F. T., Ekawarna, E., \& Rosmiati, R. (2021). BERBISNIS ONLINE MAHASISWA PENDIDIKAN EKONOMI UNIVERSITAS JAMBI 2020. 2(1), 31-46.

Elrhim, M. A., \& Elsayed, A. (2020). The Effect of COVID-19 Spread on the E-Commerce Market: The Case of the 5 Largest ECommerce Companies in the World. SSRN Electronic Journal, July. https://doi.org/10.2139/ssrn.3621166

Filbert, R., \& Prasetya, W. (2017). Investasi Saham Ala Fundamentalis Dunia (A. Subandi (ed.)). PT elex Media Komputindo Gramedia.

Hasanah, H. (2017). TEKNIK-TEKNIK OBSERVASI (Sebuah Alternatif Metode Pengumpulan Data Kualitatif Ilmu-ilmu Sosial). AtTaqaddum, 8(1), 21. https://doi.org/10.21580/at.v8i1.1163

Jati, H., Cendana, U. N., Makatita, R. F., Mikro, U., \& Kreatif, E. (2021). Seminar Nasional Manajemen dan Call for Paper ( SENIMA 5 ) Dampak Covid 19 Terhadap UMK dan Pentingnya Literasi Keuangan dan Teknologi dalam Mempertahankan Kelangsungan Bisnis Kuliner di Kota Kupang. January.

Kirana, J., Rajagukguk, K. P., Lailan, E., \& Lubis, S. (2020). ANALISIS DAMPAK COVID-19 PADA MASYARAKAT. 1, 64-69.

van der Westhuizen, T., \& Goyayi, M. J. (2020). The influence of technology on entrepreneurial self-efficacy development for online business start-up in developing nations. International Journal of Entrepreneurship and Innovation, 21(3), 168-177. https://doi.org/10.1177/1465750319889224

WIDIANINGRUM; Enggar. (2020). PENGARUH EFIKASI DIRI DAN LINGKUNGAN KELUARGA TERHADAP MINAT


http://ejournals.umma.ac.id/index.php/point/article/view/726

Yushita, A. N. (2017). Pentingnya Literasi Keuangan Bagi Pengelolaan Keuangan Pribadi. Nominal, Barometer Riset Akuntansi Dan Manajemen, 6(1). https://doi.org/10.21831/nominal.v6i1.14330 